\title{
Comparison of right and left common carotid arteries of horses and mules by two-dimensional ultrasound and Doppler flow ${ }^{1}$
}

\author{
Jéssica L. Fogaça ${ }^{2}$ (D), Maria Cristina R. Castiglioni ${ }^{3}$, Michel C. Vettorato ${ }^{3}$, \\ Jeana P. Silva ${ }^{3}$, Laís M.C. Bueno ${ }^{3}$, André Luis Filadelpho, \\ José Nicolau P. Puoli-Filho ${ }^{3}$ and Vânia Maria V. Machado ${ }^{2 *}$ (D)
}

\begin{abstract}
Fogaça J.L., Castiglioni M.C.R., Vettorato M.C., Silva P.J., Bueno L.M.C., Filadelpho A.L., Puoli-Filho J.N.P. \& Machado V.M.V. 2020. Comparison of right and left common carotid arteries of horses and mules by two-dimensional ultrasound and Doppler flow. Pesquisa Veterinária Brasileira 40(7):564-570. Departamento de Reprodução Animal e Radiologia Veterinária, Faculdade de Medicina Veterinária e Zootecnia, Universidade Estadual Paulista "Júlio de Mesquita Filho", Rua Prof. Dr. Walter Mauricio Correra s/n, Rubião Junior, Botucatu, SP 18618-970, Brazil. E-mail: vaniamvm@fmvz.unesp.br

In ultrasonography, the bi-dimensional mode (B-mode) allows the morphological and morphometric evaluation of several types of organs and tissues, while the Doppler mode allows the hemodynamic evaluation. In humans, the Doppler evaluation is routinely used in the assessment of important arteries and veins, such as the carotid arteries and jugular veins, with significant differences between genres and sides. However, in veterinary medicine, this diagnostic method is not yet well established in the evaluation of the carotid arteries, with only few reports in domestic horses. This study aims to compare the right and left common carotid arteries of domestic horses and mules using bi-dimensional and Doppler ultrasound evaluation. The common carotid arteries from 10 domestic horses (five males and five females) and 10 mules (five males and five females) were evaluated. The following variables were measured at three different portions (cranial, middle and caudal): diameter, intima-media thickness (IMT), resistivity index (RI), pulsatility index (PI), peak of systolic velocity (pSV) and final diastolic velocity (fDV). No significant differences were observed in the bi-dimensional variables (diameter and IMT) between the common carotid arteries of horses and mules, regardless of gender ( $p>0.05)$. In Doppler mode, there were no significant differences between carotid values in male and female horses ( $p>0.05)$. In the mules, it was only possible to observe differences between the RI and PI values $(p<0.05)$, being higher on the left side $(0.81$ and 2.04 respectively), and the fDV $(\mathrm{p}<0.05)$ higher, on the right side (14.35) in males. As for females, there was only in fDV $(\mathrm{p}<0.05)$, with the upper right side (23.16). Diameters and IMT do not differ between sides in horses and mules in B-mode ultrasound. Spectral Doppler in horses does not differ between sides, regardless of gender. As for mules, males differ in RI, PI and fDV between sides, while females differ only in fDV.
\end{abstract}

INDEX TERMS: Carotid arteries, horses, mules, two-dimensional ultrasound, Doppler flow, vases, diagnostic image, blood flow.

\footnotetext{
${ }^{1}$ Received on September 16, 2019.

Accepted for publication on November 13, 2019.

${ }^{2}$ Departamento de Reprodução Animal e Radiologia Veterinária, Faculdade de Medicina Veterinária e Zootecnia (FMVZ), Universidade Estadual Paulista "Júlio de Mesquita Filho" (Unesp), Campus de Botucatu, Distrito de Rubião Junior s/n, Botucatu, São Paulo, Brazil. *Corresponding author: vaniamvm@fmvz.unesp.br

${ }^{3}$ Faculdade de Medicina Veterinária e Zootecnia (FMVZ), Universidade Estadual Paulista "Júlio de Mesquita Filho" (Unesp), Campus de Botucatu, Distrito de Rubião Junior s/n, Botucatu, São Paulo, Brazil.
}

RESUMO.- [Comparação das artérias carótidas comuns direita e esquerda dos gêneros de equinos e muares por ultrassonografia bidimensional e Dopplerfluxométrico.] Na ultrassonografia, o modo bidimensional (modo B) permite a avaliação morfológica e morfométrica de vários tipos de órgãos e tecidos, enquanto o modo Doppler permite a avaliação hemodinâmica. Em humanos, a avaliação com Doppler é usada rotineiramente na avaliação de artérias e 
veias importantes, como as artérias carótidas e veias jugulares, com diferenças significativas entre gêneros e lados. No entanto, em medicina veterinária, este método diagnóstico ainda não está bem estabelecido na avaliação das artérias carótidas, com apenas poucos relatos em equinos domésticos. Este estudo tem como objetivo comparar as artérias carótidas comuns direita e esquerda de equinos e mulas domésticos, utilizando a avaliação bidimensional (modo B) e por ultrassonografia Doppler espectral. Avaliaram-se as artérias carótidas comuns de 10 equinos domésticos (cinco machos e cinco fêmeas) e 10 mulas (cinco machos e cinco fêmeas). As seguintes variáveis foram medidas em três porções diferentes (cranial, médio e caudal): diâmetro, espessura íntima-média (IMT), índice de resistividade (RI), índice de pulsatilidade (PI), pico de velocidade sistólica (pSV) e velocidade diastólica final (fDV). Não foram observadas diferenças significativas nas variáveis bidimensionais (diâmetro e IMT) entre as artérias carótidas comuns de cavalos e muares, independentemente do gênero ( $p>0,05)$. No modo Doppler, não houve diferenças significativas entre os valores para carótidas em equinos machos e fêmeas ( $p>0,05)$. Nos muares, só foi possível observar diferenças entre os valores de RI e PI ( $\mathrm{p}<0,05)$, sendo maiores no lado esquerdo $(0,81$ e 2,04 respectivamente $)$, e o fDV $(p<0,05)$ superior no lado direito $(14,35)$ nos machos. Quanto as fêmeas, houve apenas no fDV $(\mathrm{p}<0,05)$, sendo o lado direito superior $(23,16)$. Os diâmetros e IMT não diferem entre os lados em equinos e muares na ultrassonografia modo B. Já o Doppler espectral nos equinos não difere entre os lados, independentemente do gênero. Quanto aos muares, os machos diferenciam no IR, IP e fDV entre os lados, enquanto as fêmeas apenas para fDV.

TERMOS DE INDEXAÇÃO: Artérias carótidas comuns, equinos, muares, ultrassonografia bidimensional, Dopplerfluxométrico, vasos, diagnóstico por imagem, fluxo sanguíneo.

\section{INTRODUCTION}

Doppler ultrasonography is a tool combined with B-mode ultrasonography that allows the hemodynamic evaluation of the vessels (Loizou 2014, Barlinn et al. 2018, Boyko et al. 2018, Mckenna et al. 2018, Oglat et al. 2018). The common carotid artery originates three important arteries in horses and mules: the internal carotid artery, the external carotid artery and the occipital artery. These vessels are responsible for irrigating the face and the central nervous system (Getty 1975, König \& Liebich 2013). Hemodynamic changes in the carotid artery and its branches may result in a compromise of the brain's function, resulting in damage, coma or death (Walker \& Naylor 2006, Abdelhamid et al. 2009, Mendis et al. 2011, Kandiah et al. 2014, Birmpili et al. 2018).

There are several types of studies on the common carotid artery in domestic horses (Cipone et al. 1997, Schmucker et al. 2000), as well as other animals such as dogs (Hess et al. 2003, Calderon-Arnulphi et al. 2011), sheep (Khamas et al. 1984, Valentine et al. 2011), cows (Braun \& Föhn 2005, Gregory et al. 2012), camels (Abdel-Magied \& Drommer 1989, Kiełtyka-Kurc et al. 2014) and even buffaloes (Prakash \& Rao 1976, Gregory et al. 2008, Sangwan et al. 2015). However, studies on carotid artery ultrasound are few in the literature, especially in mules.

Unlike horses, mules are hybrid animals, resulting from the crossbreeding between a jack and a mare (Salles et al.
2013, Gastal et al. 2014). Without further studies, it is not possible to use the horse's parameters for mules, due to a possible paternal influence. Therefore, this study aims to compare the sides of the common carotid arteries by conventional ultrasonography and spectral Doppler for the genera of horses and mules.

\section{MATERIALS AND METHODS}

Twenty healthy animals were used in the present study: ten crossbreed horses ( 5 males and 5 females), with mean age of 10 years and mean body mass of $394.6 \mathrm{~kg}$; and 10 mules ( 5 males and 5 females), with mean age of 9 years and mean body mass of 403.9 $\mathrm{kg}$. The inclusion criteria of the animals were: clinical (heart rate evaluation) and laboratory (blood count and biochemical) tests.

This study is in accordance with the ethical principles adopted by the National Council of Animal Control and Experimentation and the Ethical Commission in Animal Use of this faculty (Protocol No. 0100/2017).

The ultrasound examination was performed using a mobile ultrasound equipment (Healthcare model Logiq V2, Chicago/IL, USA) and high-frequency linear transducer $(8-12 \mathrm{mHz})$. The animals were manually restrained and no chemical restraint was required. The screening windows were located, clipped and the skin was soaked with $70 \%$ isopropyl alcohol and acoustic gel. Bi-dimensional and spectral Doppler images of three different regions of the right and left common carotid arteries were obtained: caudal, middle and cranial.

The anatomical spots in these regions were classified as caudal, middle and cranial measurement points. The caudal point was established by dorsoventral line tangent caudally to the seventh cervical vertebra. The middle point was considered as a dorsalventral line tangente caudally to the articular fovea of the fourth cervical vertebra. The cranial point was identified as a line tangent dorsally to the condyles of the occipital bone and ventrally to the angle of the jaw.

For spectral Doppler images, the following variables were acquired: resistivity index (RI), pulsatility index (PI), systolic velocity (pSV) and diastolic velocity (fDV) (Fig.1). Bi-dimensional images were obtained in the transverse and longitudinal planes, measuring vessel diameter and the intima-media thickness (IMT) (Fig.2).

The statistical analysis was performed using the GraphPad Prism software v.7.00 for Windows (GraphPad Software, San Diego/CA) with statistical significance set at $\mathrm{p}<0.05$. The variables RI, PI, pSV, fDV, IMT and vessel diameter were obtained for each region (cranial, mean and caudal) and analyzed jointly.

Subsequently, the variables were submitted to the Wilcoxon test for non-parametric data to compare the performance of each subject, in the sense of verifying if there are significant differences between the sides of the common carotid arteries with gender.

\section{RESULTS}

In domestic horses, regardless of gender, there were no significant difference between the right and left sides of the common carotid arteries (Table 1-4).

In the male mules, there were no significant differences in the B-mode variables between sides (Table 5), but there was a difference in the RI $(p<0.0001)$ and PI $(p=0.0002)$ values, which were higher on the left side, and in the fDV $(p=0.0005)$ value, which was higher on the right side (Table 6).

As for female mules, there were no significant differences in the B-mode variables (Table 7), but there was a difference in the Doppler variable fDV between sides $(p=0.0358)$, which was greater on the right common carotid (Table 8). 


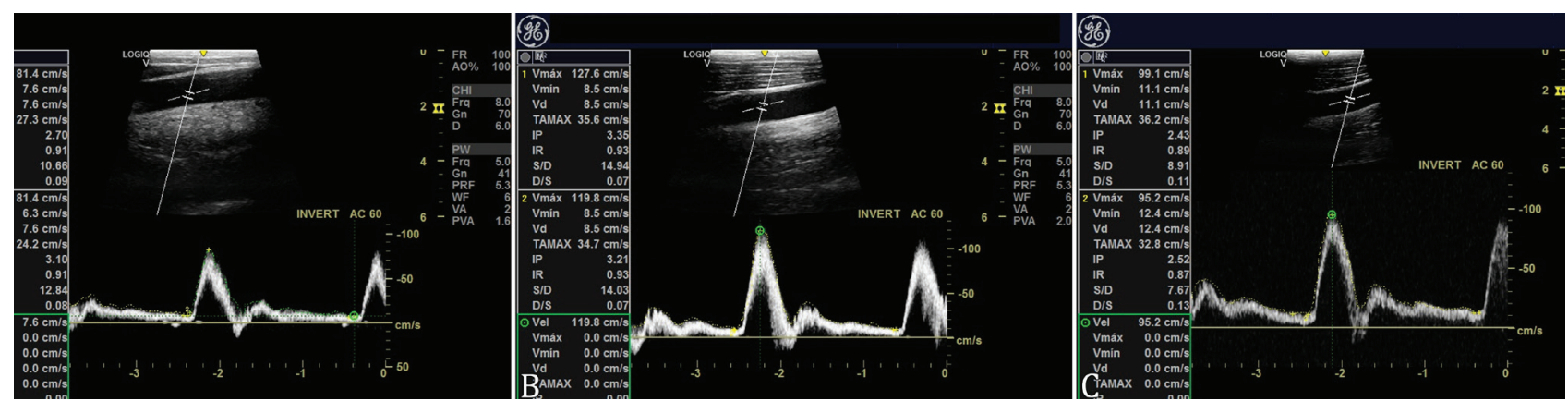

Fig.1. Doppler image acquisition in three anatomical regions: (A) caudal, (B) middle, and (C) cranial.

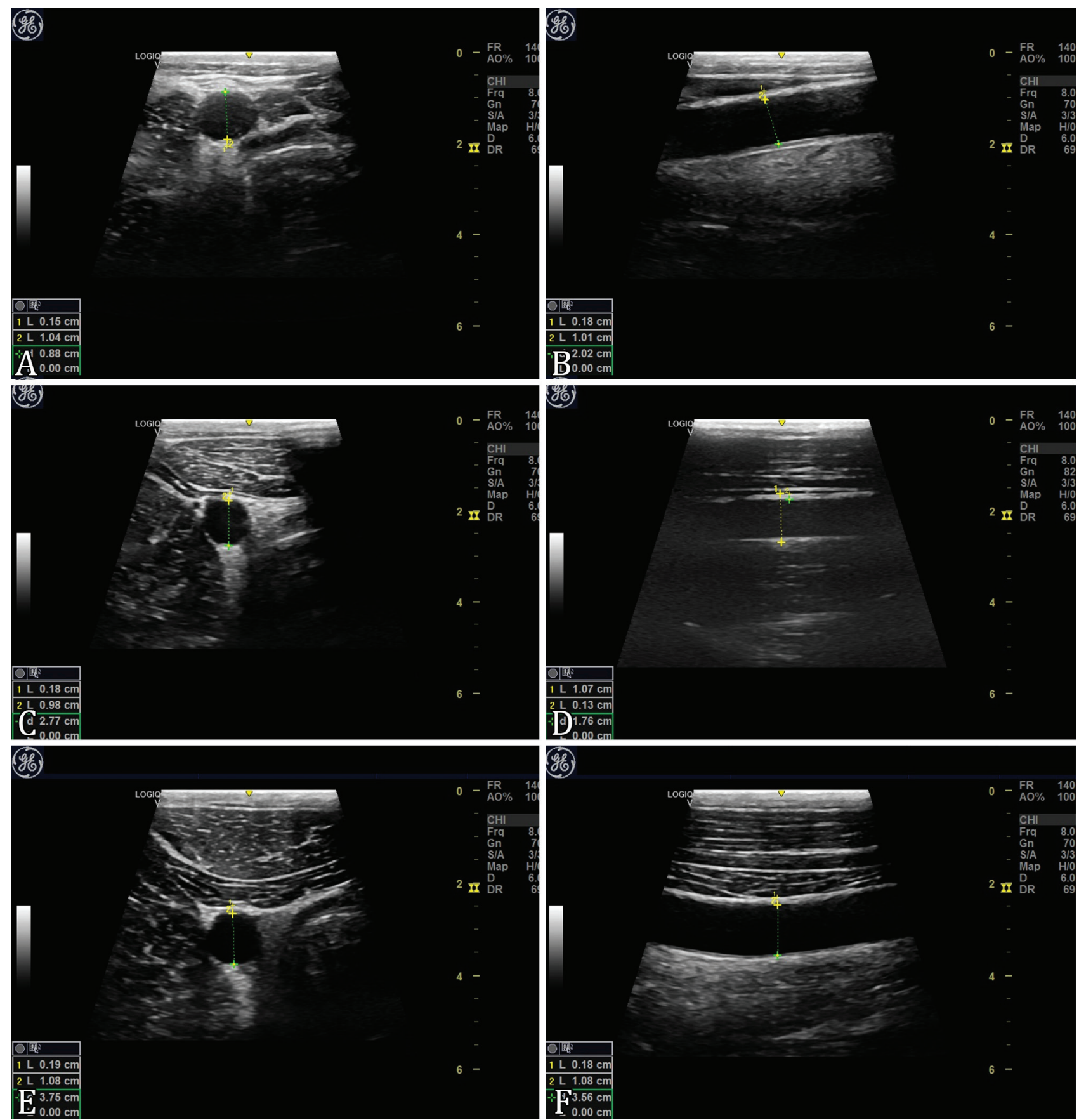

Fig.2. B-mode image acquisition in two planes for the three anatomical regions: (A) caudal in transversal and (B) longitudinal planes. Middle in (C) transversal and (D) longitudinal planes. (E) Cranial transversal and (F) longitudinal planes. 
Table 1. Descriptive analysis of bi-dimensional values for the common carotids in male horses

\begin{tabular}{|c|c|c|c|c|c|c|c|}
\hline \multirow{2}{*}{ Variables } & \multicolumn{3}{|c|}{ Right } & \multicolumn{3}{|c|}{ Left } & \multirow{2}{*}{ P-value* } \\
\hline & Mean & Median & Standard deviation & Mean & Median & Standard deviation & \\
\hline Longitudinal diameter $(\mathrm{cm})$ & 1.16 & 1.13 & 0.14 & 1.18 & 1.13 & 0.16 & 0.2992 \\
\hline Transverse diameter $(\mathrm{cm})$ & 1.26 & 1.29 & 0.18 & 1.27 & 1.26 & 0.21 & 0.4510 \\
\hline Longitudinal wall (cm) & 0.14 & 0.13 & 0.03 & 0.13 & 0.12 & 0.03 & 0.1567 \\
\hline Transverse wall $(\mathrm{cm})$ & 0.14 & 0.13 & 0.02 & 0.14 & 0.13 & 0.03 & 0.5301 \\
\hline
\end{tabular}

Table 2. Descriptive analysis of Doppler values for the common carotids in male horses

\begin{tabular}{lccccccc}
\hline \multirow{2}{*}{ Variables } & \multicolumn{4}{c}{ Right } & \multicolumn{4}{c}{ Left } \\
\cline { 2 - 6 } & Mean & Median & Standard deviation & Mean & Median & Standard deviation & P-value* \\
\hline RI & 0.81 & 0.83 & 0.07 & 0.83 & 0.83 & 0.07 & 0.5989 \\
PI & 2.06 & 2.11 & 0.56 & 2.09 & 2.09 & 0.45 & 0.5296 \\
pSV (cm/s) & 98.69 & 97.67 & 23.69 & 105.70 & 99.11 & 26.37 & 0.9635 \\
fDV (cm/s) & 16.06 & 13.98 & 8.12 & 16.00 & 15.40 & 7.58
\end{tabular}

$\mathrm{RI}=$ Resistivity index, $\mathrm{PI}=$ pulsatility index, $\mathrm{pSV}=$ peak of systolic velocity, fDV = final diastolic velocity; * P-value $<0.05$.

Table 3. Descriptive analysis of bi-dimensional values for the common carotids in female horses

\begin{tabular}{|c|c|c|c|c|c|c|c|}
\hline \multirow{2}{*}{ Variables } & \multicolumn{3}{|c|}{ Right } & \multicolumn{3}{|c|}{ Left } & \multirow{2}{*}{ P-value* } \\
\hline & Mean & Median & Standard deviation & Mean & Median & Standard deviation & \\
\hline Longitudinal diameter $(\mathrm{cm})$ & 1.10 & 0.08 & 0.07 & 1.12 & 1.11 & 0.06 & 0.4100 \\
\hline Transverse diameter $(\mathrm{cm})$ & 1.15 & 1.16 & 0.06 & 1.14 & 1.12 & 0.10 & 0.2928 \\
\hline Longitudinal wall (cm) & 0.14 & 0.14 & 0.03 & 0.12 & 0.13 & 0.02 & 0.0779 \\
\hline Transverse wall $(\mathrm{cm})$ & 0.14 & 0.15 & 0.02 & 0.15 & 0.19 & 0.03 & 0.7059 \\
\hline
\end{tabular}

* P-value $<0.05$.

Table 4. Descriptive analysis of Doppler values for the common carotids in female horses

\begin{tabular}{|c|c|c|c|c|c|c|c|}
\hline \multirow{2}{*}{ Variables } & \multicolumn{3}{|c|}{ Right } & \multicolumn{3}{|c|}{ Left } & \multirow{2}{*}{ P-value* } \\
\hline & Mean & Median & Standard deviation & Mean & Median & Standard deviation & \\
\hline RI & 0.83 & 0.83 & 0.05 & 0.82 & 0.83 & 0.06 & 0.3240 \\
\hline PI & 2.15 & 2.11 & 0.38 & 2.09 & 2.06 & 0.44 & 0.2373 \\
\hline $\mathrm{pSV}(\mathrm{cm} / \mathrm{s})$ & 104.90 & 102.10 & 11.99 & 108.50 & 108.00 & 16.84 & 0.2702 \\
\hline $\mathrm{fDV}(\mathrm{cm} / \mathrm{s})$ & 11.78 & 15.99 & 5.13 & 16.97 & 17.55 & 5.04 & 0.0649 \\
\hline
\end{tabular}

RI = Resistivity index, $\mathrm{PI}=$ pulsatility index, pSV = peak of systolic velocity, fDV = final diastolic velocity; ${ }^{*} \mathrm{P}$-value $<0.05$.

Table 5. Descriptive analysis of bi-dimensional values for the common carotids in male mules

\begin{tabular}{|c|c|c|c|c|c|c|c|}
\hline \multirow{2}{*}{ Variables } & \multicolumn{3}{|c|}{ Right } & \multicolumn{3}{|c|}{ Left } & \multirow{2}{*}{ P-value* } \\
\hline & Mean & Median & Standard deviation & Mean & Median & Standard deviation & \\
\hline Longitudinal diameter $(\mathrm{cm})$ & 1.31 & 1.31 & 0.08 & 1.29 & 1.26 & 0.11 & 0.5300 \\
\hline Transverse diameter $(\mathrm{cm})$ & 1.29 & 1.30 & 0.08 & 1.30 & 1.29 & 0.07 & 0.8012 \\
\hline Longitudinal wall (cm) & 0.15 & 0.15 & 0.03 & 0.15 & 0.15 & 0.03 & 0.8886 \\
\hline Transverse wall (cm) & 0.14 & 0.15 & 0.03 & 0.14 & 0.13 & 0.03 & 0.8505 \\
\hline
\end{tabular}

* P-value $<0.05$.

Table 6. Descriptive analysis of Doppler values for the common carotids in male mules

\begin{tabular}{|c|c|c|c|c|c|c|c|}
\hline \multirow{2}{*}{ Variables } & \multicolumn{3}{|c|}{ Right } & \multicolumn{3}{|c|}{ Left } & \multirow{2}{*}{ P-value } \\
\hline & Mean & Median & Standard deviation & Mean & Median & Standard deviation & \\
\hline RI & 0.74 & 0.73 & 0.11 & 0.79 & 0.81 & 0.08 & $<0.0001^{*}$ \\
\hline PI & 1.76 & 1.64 & 0.71 & 2.00 & 2.04 & 0.52 & $0.0002^{*}$ \\
\hline $\mathrm{pSV}(\mathrm{cm} / \mathrm{s})$ & 63.91 & 61.98 & 8.04 & 62.76 & 61.92 & 11.71 & 0.7329 \\
\hline $\mathrm{fDV}(\mathrm{cm} / \mathrm{s})$ & 14.35 & 11.63 & 7.91 & 11.48 & 10.22 & 6.2 & $0.0005^{*}$ \\
\hline
\end{tabular}

RI = Resistivity index, PI = pulsatility index, pSV = peak of systolic velocity, fDV = final diastolic velocity; ${ }^{*}$ P-value $<0.05$. 
Table 7. Descriptive analysis of bi-dimensional values for the common carotids in female mules

\begin{tabular}{lcccccc}
\hline \multirow{2}{*}{ Variables } & \multicolumn{4}{c}{ Right } & \multicolumn{3}{c}{ Left } \\
\cline { 2 - 6 } Pean & Median & Standard deviation & Mean & Median & Standard deviation \\
\hline Longitudinal diameter $(\mathrm{cm})$ & 0.14 & 0.15 & 0.03 & 1.15 & 1.13 & 0.12 \\
Transverse diameter (cm) & 1.16 & 1.14 & 0.16 & 1.19 & 1.16 & 0.9250 \\
Longitudinal wall (cm) & 0.14 & 0.14 & 0.04 & 0.14 & 0.15 & 0.13 \\
Transverse wall (cm) & 0.14 & 0.15 & 0.03 & 0.16 & 0.16 & 0.03 \\
\hline
\end{tabular}

Table 8. Descriptive analysis of Doppler values for the common carotids in female mules

\begin{tabular}{|c|c|c|c|c|c|c|c|}
\hline \multirow{2}{*}{ Variables } & \multicolumn{3}{|c|}{ Right } & \multicolumn{3}{|c|}{ Left } & \multirow{2}{*}{ P-value } \\
\hline & Mean & Median & Standard deviation & Mean & Median & Standard deviation & \\
\hline RI & 0.71 & 0.71 & 0.09 & 0.72 & 0.72 & 0.08 & 0.0678 \\
\hline PI & 1.48 & 1.38 & 0.41 & 1.56 & 1.42 & 0.52 & 0.3099 \\
\hline $\mathrm{pSV}(\mathrm{cm} / \mathrm{s})$ & 83.00 & 83.34 & 14.61 & 83.58 & 84.24 & 9.89 & 0.9284 \\
\hline $\mathrm{fDV}(\mathrm{cm} / \mathrm{s})$ & 24.06 & 23.16 & 9.43 & 21.67 & 22.52 & 8.11 & $0.0358^{*}$ \\
\hline
\end{tabular}

$\mathrm{RI}=$ Resistivity index, $\mathrm{PI}=$ pulsatility index, $\mathrm{pSV}=$ peak of systolic velocity, $\mathrm{fDV}=$ final diastolic velocity; ${ }^{*} \mathrm{P}$-value $<0.05$.

\section{DISCUSSION}

There are studies regarding B-mode and Spectral Doppler ultrasonography in the common carotid arteries of horses (Cipone et al. 1997, Schmucker et al. 2000, Aguiar 2015), but a review of the literature revealed no such studies involving mules. Unlike the results reported in the literature, this study did not observe differences between each side of the carotids in horses. According to Aguiar (2015), American Quarter Horses have common carotid arteries that are larger on the right side than on the left, but this study did not observe this difference in the diameter measurements obtained through B-mode ultrasound. This discrepancy may be related to the fact that this study only used animals with similar ages (adults), which could make it impossible to observe the asymmetry.

In human medicine, it is possible to observe the influence of age and even sex on the sonographic characteristics. The right carotid artery differentiates anatomically from the left and this may be related to hemodynamics, age, sex, hormone levels and other factors that may predispose this difference (Luo et al. 2011). A study has demonstrated that women had larger right-side diameter than the left side (Krejza et al. 2006). However, this difference in diameter was not observed in female horses and mules. As for men, Denarié et al. (2000) reported that diameters of the right common carotid arteries were larger than the those of the left. A study conducted by Krejza et al. (2006) did not verify this difference between the sides in men, and this study also did not observe such difference in male horses and mules.

For the IMT of the common carotid arteries of horses and mules, the difference between the sides was not significant, similar to the findings observed by Aguiar (2015), in which the IMT was not associated with the genus and sides of the animals evaluated. However, in a study by Rosfors et al. (1998), the carotid artery on the left side of men presented higher IMT values than the right side, and this may be related to the faster development of the atherosclerotic plaques in the carotid artery on the left side. According to Loizou et al. (2015), people who have not undergone cardiovascular changes do not present differences between left and right IMT. Atherosclerotic plaques deposited in the common carotid arteries are not as frequent in animals as they are in humans, where considered one of major causes of mortality in the world (Mendis et al. 2011, Ricotta et al. 2011, Barlinn et al. 2018, Boyko et al. 2018, Evans et al. 2018, Mckenna et al. 2018, Oglat et al. 2018).

In the Doppler ultrasonography, there were differences in male mules, with RI and PI having the highest values on the left side, while fDV was higher on the right side. According to Aguiar (2015), RI did not change according to gender and side in American Quarter Horses, which is in line with the results observed in horses (undefined breed) in this study. However, Doppler variations were observed in male and female mules.

The pSV variable was not significantly different between the sides for the mules. The measurement of pSV and fDV is an important tool in the detection of stenosis (Tortoli et al. 2015). In addition, RI and PI provide information about blood flow and vessel impedance (Oglat et al. 2018). The blood flow in these vessels becomes more resistant as horses age (Aguiar 2015). In healthy elderly humans, pSV and fDV were $50 \%$ lower than in younger individuals, which can be explained by vascular compliance (PI) (Wolff et al. 2007).

In healthy humans, there may be differences in the blood flow velocity of common carotid arteries between the sides (Holdsworth et al. 1999), as was the case in mules in this study. These differences may be related to the fact that they are hybrid animals and present anatomical and physiological differences in comparison to horses (Burnham 2002, Alsafy et al. 2008, Smith 2009).

An ultrasound evaluation by spectral Doppler in dogs did not demonstrate differences between the sides of the common carotid arteries (Svicero et al. 2013) similar to male and females horses in this study. According to Aguiar (2015), there may be differences according to breed or influence of sex hormones on the blood flow and vessel structures.

Schmucker et al. (2000) evaluated the common carotid arteries of anesthetized and sedated horses, which altered the blood flow velocity and vessel diameters, respectively. For this reason, this study avoided adequate chemical containment and adopted handling procedures avoiding animal stress to inhibit possible hemodynamic and structural changes. 
The results observed in this study highlighted the possibility of inequalities between the variables obtained by spectral Doppler ultrasonography in the right and left common carotid arteries, so that these data can guide the professionals in the evaluation of this vessel in horses and mules, either within the respective genera or in comparison with other species. Above all, due to these differences, we recommend that, during investigations of the common carotid arteries of horses and mules by spectral Doppler ultrasonography, the vessels should be evaluated on both sides.

\section{CONCLUSIONS}

The diameters and IMT of the common carotid arteries do not differ between the sides in horses and mules during B-mode ultrasonography.

Spectral Doppler in horses does not differ between sides, regardless of gender.

As for the mules, the males present differences between the sides for the variables RI, PI and fDV, while females so only for fDV.

Conflict of interests statement.- The authors declare no conflict of interests.

\section{REFERENCES}

Abdelhamid M.F., Wall M.L. \& Vohra R. K. 2009. Carotid artery pseudoaneurysm after carotid endarterectomy: case series and a review of the literature. Vasc. Endovasc. Surg. 43(6):571-577.<http://dx.doi.org/10.1177/1538574409334827>. <PMid:19640914>

Abdel-Magied E.M. \& Drommer W. 1989. Structure of the carotid sinus of the dromedary camel (Camelus dromedarius). Anat. Histol. Embryol. 18(4):316-326. <http://dx.doi.org/10.1111/j.1439-0264.1989.tb00605.x>

Aguiar A.C.S.D. 2015. Avaliação ultrassonográfica da artéria carótida comum em equinos da raça Quarto de Milha. Master's Thesis, Faculdade de Medicina Veterinária e Zootecnia, Universidade Estadual Paulista "Júlio de Mesquita Filho", Botucatu, SP. 77p.

Alsafy M.A.M., El-Kammar M.H. \& El-Gendy S.A.A. 2008. Topographical anatomy, computed tomography, and surgical approach of the guttural pouches of the donkey. J. Equine Vet. Sci. 28(4):215-222. <http://dx.doi.org/10.1016/j.jevs.2008.02.005>

Barlinn K., Rickmann H., Kitzler H., Krogias C., Strohm H., Abramyuk Barlinn J., Siepmann T., Rabahi A., Graehlert X., Schwanebeck U., Winzer S., Arnold S., Moennings P., Pallesen L.-P., Bodechtel U., Mudra H., Linn J., Reichmann H., Alexandrov A.V., Gahn G., Weiss N. \& Puetz V. 2018. Validation of multiparametric ultrasonography criteria with digital subtraction angiography in carotid artery disease: a prospective multicenter study. Ultraschall Med., Euro J. Ultrasound., Stuttgart, 39(5):535-543. <http://dx.doi.org/10.1055/s-0043-119355><PMid:29797307>

Birmpili P., Porter L., Shaikh U. \& Torella F. 2018. Comparison of measurement and grading of carotid stenosis with computed tomography angiography and doppler ultrasound. Ann. Vasc. Surg. 51:217-224. <http://dx.doi.org/10.1016/j.avsg.2018.01.102><PMid:29522870>

Boyko M., Kalashyan H., Becher H., Romanchuk H., Saqqur M., Rempel J.L., Derksen C., Shuaib A. \& Khan K. 2018. Comparison of carotid doppler ultrasound to other angiographic modalities in the measurement of carotid artery stenosis. J. Neuroimag. 28(6):683-687. <http://dx.doi.org/10.1111/ jon.12532><PMid:29917285>

Braun U. \& Föhn J. 2005. Duplex ultrasonography of the common carotid artery and external jugular vein of cows. Am. J. Vet. Res. 66(6):962-965. <http://dx.doi.org/10.2460/ajvr.2005.66.962><PMid:16008216>

Burnham S.L. 2002. Anatomical differences of the donkey and mule. AAEP Proc. 48(1):102-109.
Calderon-Arnulphi M., Amin-Hanjani S., Alaraj A., Zhao M., Du X., Ruland S., Zhou X.J., Thulborn K.R. \& Charbel F.T. 2011. In vivo evaluation of quantitative MR angiography in a canine carotid artery stenosis model. Am. J. Neuroradiol. 32(8):1552-1559. <http://dx.doi.org/10.3174/ajnr. A2546><PMid:21835941>

Cipone M., Pietra M., Gandini G., Borai A., Guglielmini C. \& Venturoli M. 1997. Pulsed wave-doppler ultrasonographic evaluation of the common carotid artery in the resting horse: physiologic data. Vet. Radiol. Ultrasound 38(3):200-206.<http://dx.doi.org/10.1111/j.1740-8261.1997.tb00841.x>

Denarié N., Gariepy J., Chironi G., Massonneau M., Laskri F., Salomon J., Levenson J. \& Simon A. 2000. Distribution of ultrasonographically-assessed dimensions of common carotid arteries in healthy adults of both sexes. Atherosclerosis 148(2):297-302. <http://dx.doi.org/10.1016/S00219150(99)00276-2><PMid:10657565>

Evans K., Birk G.K. \& Antoniou G.A. 2018. Diagnosing pseudoaneurysm of the extracranial carotid arteries using doppler ultrasonography: a case report. J. Vasc. Ultrasound 42(3):123-126. <http://dx.doi. org $/ 10.1177 / 1544316718782931>$

Gastal E.L., Barros L.O., Carneiro G.F. \& Gastal M.O. 2014. Follicular dynamics in mules. J. Equine Vet. Sci. 34(1):144. <http://dx.doi.org/10.1016/j. jevs.2013.10.099>

Getty R. 1975. Sisson and Grossman's, The Anatomy of the Domestic Animals. 5th ed. W.B. Saunders, Philadelphia. 2130p.

Gregory N.G., Schuster P., Mirabito L., Kolesar R. \& McManus T. 2012. Arrested blood flow during false aneurysm formation in the carotid arteries of cattle slaughtered with and without stunning. Meat Sci. 90(2):368-372. <http://dx.doi.org/10.1016/j.meatsci.2011.07.024>

Gregory N.G., Von-Wenzlawowicz M., Alam R.M., Anil H.M., Yeșildere T. \& Silva-Fletcher A. 2008. False aneurysms in carotid arteries of cattle and water buffalo during shechita and halal slaughter. Meat Sci. 79(2):285-288. <http://dx.doi.org/10.1016/j.meatsci.2007.09.012><PMid:22062756>

Hess R.S., Kass P.H. \& VanWinkle T.J. 2003. Association between diabetes mellitus, hypothyroidism or hyperadrenocorticism, and atherosclerosis in dogs. J. Vet. Intern. Med. 17(4):489-494.<http://dx.doi.org/10.1111/j.1939-1676.2003. tb02469.x $><$ PMid:12892299>

Holdsworth D.W., Norley C.J.D., Frayne R., Steinman D.A. \& Rutt B.K. 1999. Characterization of common carotid artery blood-flow waveforms in normal human subjects. Physiol. Measurement 20(3):219. <http://dx.doi.org/10.1088/0967-3334/20/3/301><PMid:10475577>

Kandiah N., Goh O., Mak E., Marmin M. \& Ng A. 2014. Carotid stenosis: a risk factor for cerebral white-matter disease. J. Stroke Cerebrovasc. Dis. 23(1):136139. <http://dx.doi.org/10.1016/j.jstrokecerebrovasdis.2012.11.007> $<$ PMid:23265783>

Khamas W.A., Ghoshal N.G. \& Bal H.S. 1984. Histomorphologic structure of the carotid rete-cavernous sinus complex and its functional importance in sheep (Ovis aries). Am. J. Vet. Res. 45(1):156-158. <PMid:6703449>

Kiełtyka-Kurc A., Frąckowiak H., Zdun M., Nabzdyk M., Kowalczyk K. \& Tołkacz M. 2014. The arteries on the base of the brain in the camelids (Camelidae). Italian J. Zool. 81(2):215-220. <http://dx.doi.org/10.1080 /11250003.2014.901428>

König H.E. \& Liebich H.G. 2013. Veterinary Anatomy of Domestic Mammals: textbook and colour atlas. Schattauer Verlag. 788p.

Krejza J., Arkuszewski M., Kasner S.E., Weigele J., Ustymowicz A., Hurst R.W., Cucchiara B.L. \& Messe S.R. 2006. Carotid artery diameter in men and women and the relation to body and neck size. Stroke 37(4):1103-1105. <http://dx.doi.org/10.1161/01.STR.0000206440.48756.f7><PMid:16497983>

Loizou C.P. 2014. A review of ultrasound common carotid artery image and video segmentation techniques. Med. Biol. Engin. Computing 52(12):10731093. <http://dx.doi.org/10.1007/s11517-014-1203-5><PMid:25284219>

Loizou C.P., Nicolaides A., Kyriacou E., Georghiou N., Griffin M. \& Pattichis C.S. 2015. A comparison of ultrasound intima-media thickness measurements 
of the left and right common carotid artery. IEEE J. Transl. Engin. in Health Med. 3:1900410. <http://dx.doi.org/10.1109/JTEHM.2015.2450735> <PMid:27170894>

Luo X., Yang Y., Cao T. \& Li Z. 2011. Differences in left and right carotid intimamedia thickness and the associated risk factors. Clin. Radiol. 66(5):393398. <http://dx.doi.org/10.1016/j.crad.2010.12.002><PMid:21324442>

Mckenna M.A., Bonfield M.C. \& Robinson T. 2018. Levels of agreement in the measurements of carotid artery ultrasound across a regional vascular network. Ultrasound 26(2):101-109. <http://dx.doi.org/10.1177/1742271X17751255> $<$ PMid:30013610>

Mendis S., Puska P. \& Norrving B. 2011. Global Atlas on Cardiovascular Disease Prevention and Control. World Health Organization, Geneva. 164p.

Oglat A.A., Matjafri M.Z., Suardi N., Oqlat M.A., Abdelrahman M.A. \& Oqlat A.A. 2018. A review of medical doppler ultrasonography of blood flow in general and especially in common carotid artery. J. Med. Ultrasound 26(1):3-13. <http://dx.doi.org/10.4103/JMU.JMU_11_17> <PMid:30065507>

Prakash P. \& Rao G.S. 1976. A morphological study of the carotid body and the fibre content of carotid nerve in the buffalo. Cells Tissues Organs 95(2):249-259. <http://dx.doi.org/10.1159/000144617><PMid:961356>

Ricotta J.J., AbuRahma A., Ascher E., Eskandari M., Faries P. \& Lal B.K. 2011. Updated Society for Vascular Surgery guidelines for management of extracranial carotid disease. J. Vasc. Surg. 54(3):e1-e31. <http://dx.doi. org/10.1016/j.jvs.2011.07.031> <PMid:21889701>

Rosfors S., Hallerstam S., Jensen-Urstad K. \& Zetterling M. \& Carlström C. 1998. Relationship between intima-media thickness in the common carotid artery and atherosclerosis in the carotid bifurcation. Stroke 29(7):13781382. <http://dx.doi.org/10.1161/str.29.7.1378>

Salles P.A., Souza L.O., Gomes L.P.B., Barbosa V.V., Medeiros G.R. \& Souza C.M. 2013. Analysis of the population of equidae in semiarid region of Paraíba. J. Biotechonol. Biodiversity 4(3):269-275.
Sangwan V., Mohindroo J., Kumar A., Mukhopadhyay C.S. \& Saini N.S. 2015. Doppler ultrasonography of common carotid artery and external jugular vein in healthy and reticulo-diaphragmatic hernia affected buffaloes. Proc. Natl Acad. Sci., India Section B, Biol. Sci. 85(3):859-865. <http://dx.doi. org/10.1007/s40011-014-0402-z>

Schmucker N., Schatzmann U., Budde K., Gundel M., Jáuggin C.E. \& Meier H.P. 2000. Duplex-ultrasonographic evaluation of the common carotid artery in the resting, sedated and anesthetized horse. Vet. Radiol. Ultrasound 41(2):168-171.<http://dx.doi.org/10.1111/j.1740-8261.2000.tb01472.x> <PMid:10779078>

Smith D.C. 2009. The Book of Mules: selecting, breeding and caring for equine hybrids. The Lyons Press, Conecticut. 136p.

Svicero D.J., Doiche D.P., Mamprim M.J., Heckler C.M.T \& Amorim R.M. 2013. Ultrasound evaluation of common carotid artery blood flow in the Labrador retriever. BMC Vet. Res. 9(1):195. <http://dx.doi.org/10.1186/17466148-9-195>

Tortoli P., Lenge M., Righi D., Ciuti G., Liebgott H. \& Ricci S. 2015. Comparison of carotid artery blood velocity measurements by vector and standard Doppler approaches. Ultrasound Med. Biol. 41(5):1354-1362. <http:// dx.doi.org/10.1016/j.ultrasmedbio.2015.01.008> <PMid:25722028>

Valentine R., Boase S., Jervis-Bardy J., Dones-Cabral J.D., Robinson S. \& Wormald P.J. 2011. The efficacy of hemostatic techniques in the sheep model of carotid artery injury. Int. Forum Allergy Rhinol. 1(2):118-122. <http://dx.doi.org/10.1002/alr.20033> <PMid:22287330>

Walker J. \& Naylor A.R. 2006. Ultrasound based measurement of 'carotid stenosis $>70 \%$ ': an audit of UK practice. Euro J. Vasc. Endovasc. Surg. 31(5):487-490. <http://dx.doi.org/10.1016/j.ejvs.2005.11.029>

Wolff T., Guirguis-Blake J., Miller T., Gillespie M. \& Harris R. 2007. Screening for carotid artery stenosis: an update of the evidence for the US Preventive Services Task Force. Ann. Intern. Med. 147(12):860-870. <http://dx.doi. org/10.7326/0003-4819-147-12-200712180-00006><PMid:18087057> 